\title{
The PI 3-kinase/Akt signaling pathway delivers an anti-apoptotic signal
}

\author{
Scott G. Kennedy, ${ }^{1,2}$ Andrew J. Wagner, ${ }^{1}$ Suzanne D. Conzen, ${ }^{1}$ Joaquín Jordán, ${ }^{2}$ Alfonso Bellacosa, ${ }^{3}$ \\ Philip N. Tsichlis, ${ }^{3}$ and Nissim Hay ${ }^{1,2,4}$ \\ ${ }^{1}$ The Ben May Institute for Cancer Research and ${ }^{2}$ Department of Pharmacological and Physiological Sciences, The \\ University of Chicago, Chicago, Illinois 60637 USA; $^{3}$ Fox Chase Cancer Center, Philadelphia, Pennsylvania 19111 USA
}

\begin{abstract}
Serum and certain growth factors have the ability to inhibit programmed cell death (apoptosis) and promote survival. The mechanism by which growth factors deliver an anti-apoptotic signal and the mechanism by which this survival signal is uncoupled from mitogenesis are not clear. We studied five downstream effectors of growth factor receptors-Ras, Raf, Src, phosphoinositide 3-kinase (PI 3-kinase), and Akt (PKB)-for their abilities to block apoptosis. Activated forms of Ras, Raf, and Src, although transforming, were not sufficient to deliver a survival signal upon serum withdrawal. In contrast, inhibition of PI 3-kinase accelerated apoptosis, and an activated form of the serine/threonine kinase Akt, a downstream effector of PI 3-kinase, blocked apoptosis. The ability of Akt to promote survival was dependent on and proportional to its kinase activity. In Rat1a fibroblasts, activated Akt did not alter Bcl-2 or Bcl- $X_{L}$ expression but inhibited Ced3/ICE-like activity. Thus, the PI 3-kinase/Akt (PKB) signaling pathway transduces a survival signal that ultimately blocks Ced3/ICE-like activity. These results suggest that uncoupling of survival and mitogenesis can be explained by differing abilities of distinct mitogens to efficiently induce the PI 3-kinase/Akt signaling pathway.
\end{abstract}

[Key Words: Growth factors; Myc; cell survival; CPP32]

Received December 24, 1996; revised version accepted February 11, 1997.

Programmed cell death and apoptosis have a fundamental role in animal development and tissue homeostasis (Ellis et al. 1991; Korsmeyer 1995; Steller 1995). Growth factors, cytokines, and serum provide both mitogenic and anti-apoptotic signals to cells and therefore play an important role in maintaining the homeostatic balance between cell proliferation and cell death (Raff et al. 1993). The mitogenic effects of these factors have been well described, and a growing body of literature has demonstrated that their withdrawal can induce programmed cell death in several cell systems (Koury and Bondrant 1990; Yonish-Rouach et al. 1991; Askew et al. 1993; Raff et al. 1993; Harrington et al. 1994). Although much is known about the signaling events involved in the mitogenic pathway, little is known about the paths leading to inhibition of programmed cell death.

Growth factors and cytokines vary in their abilities to induce proliferation and survival, but they all act by activating their respective receptor or receptor-activated tyrosine kinases that in turn activate signal transduction pathways. However, the ability of certain growth factors to induce proliferation is not necessarily correlated with their ability to promote survival, and some growth factors and cytokines promote survival of postmitotic cells (Fairbairn et al. 1993; Raff et al. 1993; Harrington et al.

${ }^{4}$ Corresponding author.

E-MAIL nhay@ben-may.bsd.uchicago.edu; FAX (773) 702-6260.
1994). It was therefore suggested that the mechanism by which certain growth factors promote survival is different from the mechanism by which they induce mitogenesis. Moreover, mutagenic analysis of the insulin-like growth factor-I (IGF-I) receptor showed that mitogenesis, transformation, and survival-promoting properties of IGF-IR can be dissociated (Miura et al. 1995; Resnicoff et al. $1995 \mathrm{a}, \mathrm{b})$.

In fibroblasts and other cells of mesenchymal origin, serum deprivation induces apoptosis that can be accelerated dramatically by ectopic expression of the c-myc proto-oncogene. Cell death can be inhibited by serum and certain purified growth factors, including IGF-I, insulin, and platelet-derived growth factor (PDGF), but not epidermal growth factor (EGF) or fibroblast growth factor (Harrington et al. 1994). EGF is a potent mitogenic factor and a relatively poor survival factor in these cells, whereas IGF-I and PDGF are good survival and not potent mitogenic factors.

In addition to the well-established effects of deregulated mitogenic signals on tumorigenesis, deregulation of a survival signal transduced by growth factors and cytokines has also been suggested to be a critical step toward tumorigenesis. The IGF-I receptor was shown to contribute to tumorigenesis in part by promoting survival both in tissue culture and in animals (Resnicoff et al. 1995a). In pancreatic islet cells and hepatocytes, expression of IGF-II increases cell survival and promotes tumorigenesis. Furthermore, tumors develop with reduced malignancy and with a higher incidence of apoptosis in mice 
that are deficient in IGF-II /Christofori et al. 1994; Ueda and Ganem 1996).

To investigate the mechanisms by which certain growth factors mediate survival, we have analyzed several downstream effectors of growth factor receptors for their ability to promote survival. We found that signaling through Ras, Raf, and Src pathways was not sufficient to transduce the survival signal. Previous results employing mutant PDGF receptor and inhibitors of PI 3-kinase suggested that PI 3-kinase can deliver a survival signal (Yao and Cooper 1995). Because growth factors that are potent activators of a downstream effector of PI 3-kinase, the serine/threonine kinase Akt/protein kinase $B(\mathrm{PKB})$, are also potent survival factors in fibroblasts (Harrington et al. 1994; Franke et al. 1995), we examined the ability of Akt to deliver a survival signal. We found that an activated Akt was sufficient to promote survival upon growth factor withdrawal. The ability of Akt to promote survival was dependent on its kinase activity and on the activity of its upstream activator, PI 3-kinase. These results may explain why some growth factors that are mitogenic and not effective inducers of the PI 3-kinase/Akt pathway are also poor survival factors.

The apoptosis pathway in mammalian cells, as in Caenorhabditis elegans, requires coordination of positive and negative regulators. Members of the Bcl-2 family in mammalian cells, homologs of the $C$. elegans ced 9 gene, are suppressors of cell death, whereas mammalian homologs of the ced3 gene of $C$. elegans that encode the Ced3/ICE [interleukin-1 $\beta$-converting enzyme]-like proteases can actively kill cells (for review, see Ellis et al. 1991; Korsmeyer 1995; Steller 1995). Here we show that, at least in fibroblasts, Akt does not induce the expression of Bcl-2 or Bcl- $\mathrm{X}_{\mathrm{L}}$ but inhibits the activities of Ced3/ICElike proteases that specifically cleave the poly(ADP-ribose) polymerase (PARP). Thus, one mechanism by which the PI 3-kinase/Akt pathway promotes survival is by inhibiting Ced3/ICE-like activity upon growth factor withdrawal. Because there are multiple potential downstream effectors of Akt, there may be multiple mechanisms by which Akt can deliver the survival signal.

It is possible that the ability of the PI 3-kinase/Akt pathway to mediate survival has a more global role in embryonic development and in the longevity of adult tissues. Interestingly, a homolog of the mammalian PI 3-kinase catalytic subunit has been implicated recently in mediating longevity in C. elegans (Morris et al. 1996). Because several Akt homologs were found in C. elegans (Waterston et al. 1992), it remains to be determined whether Akt will also have a role in longevity.

\section{Results}

Activated Ras, Raf, and Src, although tumorigenic, cannot override apoptosis induced by serum withdrawal in conjunction with induced Myc activity

Serum and growth factors activate various signaling pathways upon binding to their cognate growth factor receptors. The best characterized downstream effectors of growth factor receptors are the Ras, Raf, and Src molecules. We therefore wanted to test whether these molecules are involved in transmitting the survival signal induced by growth factors. We first examined the ability of activated Ras, Raf, and Src to block apoptosis induced by serum withdrawal in conjunction with ectopically expressed Myc.

A conditionally active Myc (MycER), which enables induction of Myc activity upon addition of $\beta$-estradiol (E2) (Eilers et al. 1989), was introduced into Ratla fibroblasts by retroviral infection. Upon activation, Myc transforms Rat la cells in the presence of serum (Eilers et al. 1989), but accelerates apoptosis in its absence (Evan et al. 1992). A single clone of Ratla cells expressing high levels of MycER [Ratla (MycER)] was isolated and then infected with retroviruses encoding V12H-Ras, $\Delta$ Raf1, or $\mathrm{v}$-Src, the constitutively active forms of the H-Ras, Raf 1 , and Src signaling molecules. For comparable quantitation of cell death, the $b c l-2$ gene, which was shown previously to protect cells from Myc-mediated apoptosis (Bissonnette et al. 1992; Fanidi et al. 1992; Wagner et al. 1993), was also introduced into Ratla (MycER) cells. Pools of several hundred clones infected with the second retrovirus were maintained as cell lines. MycER was expressed at similar levels in all cell lines, and expression of Bcl-2, V12H-Ras, $\Delta$ Raf1, and v-Src in the different cell lines was verified by Western analysis (Fig. 1A).

To demonstrate that these proteins were functionally active, we assayed the transforming activities of the constitutively active Ras, Raf, and Src alleles by the abilities of the corresponding cell lines to grow in soft agarose (Fig. 1B). In the presence of E2 the parental Ratla (MycER) cells formed between 100 and 200 colonies $\geqslant 0.5 \mathrm{~mm}$ in diameter (data not shown). In the absence of E2, however, the MycER cells formed abortive minicolonies that averaged only $0.1-0.2 \mathrm{~mm}$ in diameter with fewer than five colonies $\geqslant 0.5 \mathrm{~mm}$. This growth was most likely attributable to basal activity of the MycER protein in the absence of E2. Ratla (MycER/Bcl-2) cells formed slightly larger colonies $(0.2-0.3 \mathrm{~mm})$ and only $20-25$ colonies $\geqslant 0.5 \mathrm{~mm}$, consistent with previous reports (Koskinen et al. 1995), presumably because Bcl-2 enables longer survival. The cell lines expressing the constitutively activated forms of Ras, Raf, and Src formed significantly more colonies $>0.5 \mathrm{~mm}$ in the absence of E2 (Fig. 1B). These results demonstrate that the activated Ras, Raf, and Src are functionally active and are able to transform Ratla cells independent of high levels of Myc activity.

To determine whether activated Ras, Raf, or Src could provide the protection from apoptosis elicited by growth factors, we examined the effect of their expression on apoptosis induced by serum withdrawal. The cell lines were incubated in $0.5 \%$ fetal calf serum (FCS) in the presence or absence of $1 \mu \mathrm{M}$ E2. The percentage of apoptotic cells was assessed $16 \mathrm{hr}$ following Myc induction by staining with 4,6-diamidino-2-phenylindole-dihydrochloride (DAPI). Fragmented and condensed nuclei were scored as apoptotic (Fig. 1C). These nuclei also scored 

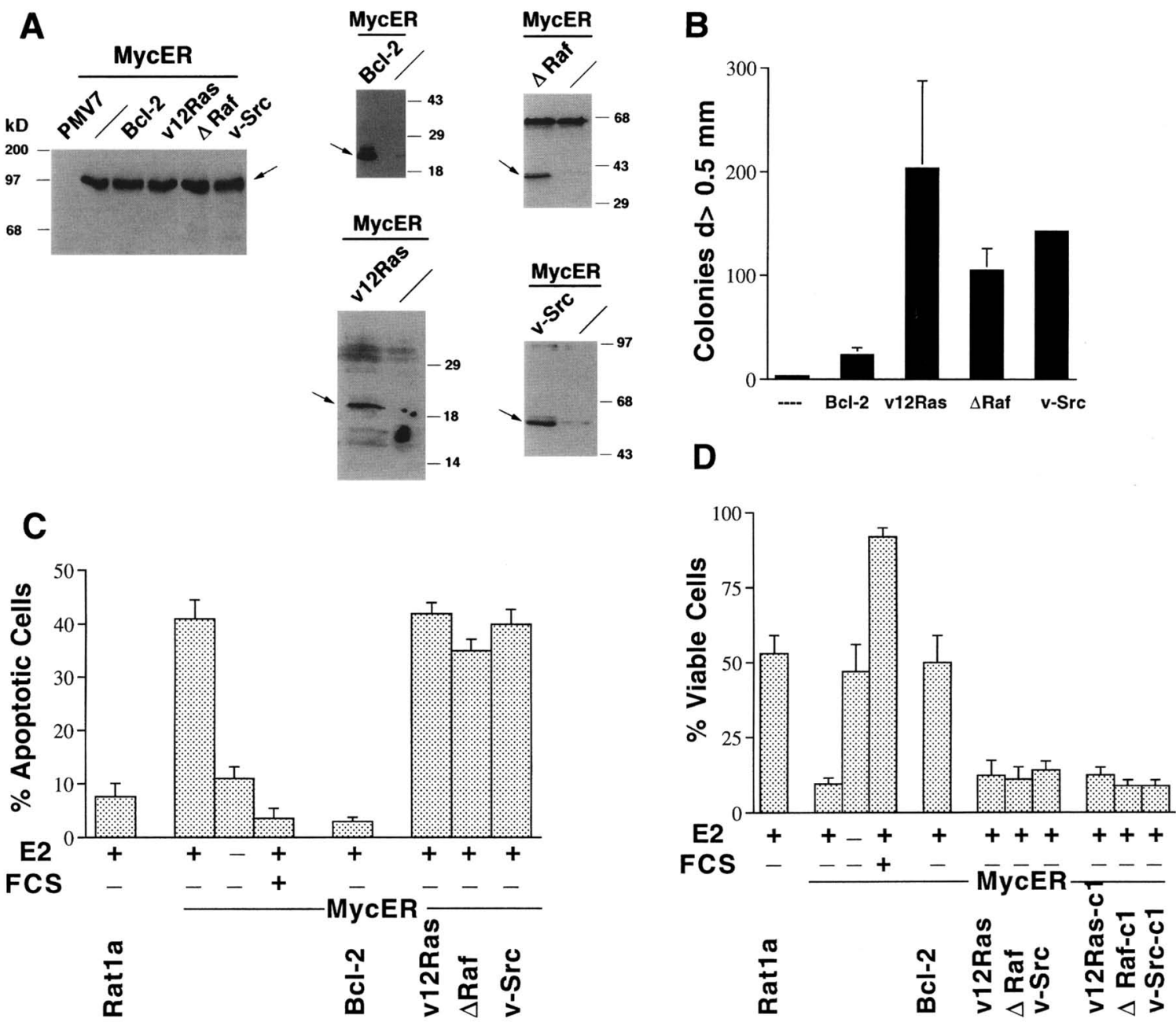

Figure 1. Constitutively active forms of H-Ras, Raf-1, and Src do not block apoptosis mediated by serum deprivation. $(A)$ Immunoblot analysis of ectopically expressed proteins in established cell lines. (Left) Expression of MycER; (right) expression levels of ectopically expressed Bcl-2, V12H-Ras, $\Delta$ Raf-1, and v-Src. Relevant proteins are indicated by arrows. Molecular size markers (in kD) are indicated. $(B)$ Quantitation of soft agarose colonies with diameter $>0.5 \mathrm{~mm}$. Five thousand Ratla (MycER) cells expressing the indicated genes were plated in soft agarose in the absence of E2; colonies were scored after 24 days. Bars represent an average of two experiments \pm standard error of the mean (S.E.). $(C)$ Percentage of apoptotic cells with or without MycER activation ( \pm E2) in 10\% (+) or $0.5 \%(-)$ FCS. Apoptosis was scored by DAPI staining after $16 \mathrm{hr}$. Averages ( \pm S.E.) of at least 500 cells from four independent experiments are shown. (D) Percentage of live cells scored by PI/FDA staining at $48 \mathrm{hr}$. Cells were treated as in $C$. Individual clones (indicated as C1) isolated from soft agarose were also examined. Averages ( \pm S.E.) of at least 200 cells from four independent experiments are shown.

positive for the terminal deoxynucleotidyl transferasemediated deoxyuridine nick end-labeling (TUNEL) reaction (not shown; see also Fig. 2).

Cell death was also measured $48 \mathrm{hr}$ after MycER activation in $0.5 \%$ FCS, using propidium iodide (PI) and fluorescein diacetate (FDA) staining (Favaron et al. 1988). Live cells hydrolyze FDA with intracellular esterases to produce yellow-green fluorescence. Loss of membrane integrity of dead cells enables PI to interact with DNA and to yield red fluorescence. After $48 \mathrm{hr}$, cells were stained with PI/FDA and the percentages of live (FDAstained) and dead (PI-stained) cells were determined (Fig. 1D).
In the presence of $10 \% \mathrm{FCS}$, only $4 \%$ of cells were scored as apoptotic after $16 \mathrm{hr}$ (Fig. 1C), and $8 \%$ after 48 hr (Fig. 1D) of MycER activation. Ratla (MycER) cells in $0.5 \%$ FCS and in the absence of E2 exhibited a baseline level of cell death that was slightly higher than that observed for Ratla cells following serum deprivation (Fig. 1C,D). This is likely to be a result of the basal MycER activity that was also observed in the soft agarose assay (Fig. 1B). No significant differences in the levels of cell death were observed between the parental Ratla (MycER) cell line and the Ratla (MycER/V12H-Ras), (MycER/DRaf), and (MycER/v-Src) cell lines. Ratla (MycER/ Bcl-2) cells, however, were significantly protected from 
Myc-accelerated apoptosis. As assessed by DAPI staining after $16 \mathrm{hr}$ of MycER activation, $36 \%-46 \%$ of the cells were apoptotic in all cell lines except the MycER/Bcl-2 cells, which exhibited $<4 \%$ cell death (Fig. 1C). After 48 hr, all cell lines, with the exception of Ratla (MycER/ Bcl-2), showed $86 \%-91 \%$ cell death as measured by the PI/FDA assay (Fig. 1D). Similar results were obtained for individual clones isolated from soft agarose (Fig. 1D). Thus, although stably expressed, activated Ras, Raf, and Src can transform these cells, each is insufficient to deliver the anti-apoptotic signal generated by serum.

\section{Inhibition of PI 3-kinase overrides the survival signal induced by serum}

It was shown previously that wortmannin, a selective inhibitor of PI 3-kinase, blocks growth factor-induced survival of PC12 cells by a Ras-independent mechanism (Yao and Cooper 1995). We therefore tested the effect of wortmannin on Myc-accelerated apoptosis. Rat la (MycER) cells were grown for $24 \mathrm{hr}$ in $1.5 \% \mathrm{FCS}$, then treated with $1 \mu \mathrm{M}$ E2 for $1 \mathrm{hr}$ for activation of MycER. Cells were rinsed and placed in DMEM with $0.01 \%$ DMSO or 200 $\mathrm{nM}$ wortmannin for $20 \mathrm{~min}$; then $5 \%$ FCS was added back to the cells, which were stained with DAPI and TUNEL 4 hr later. In the absence of wortmannin, very little cell death was observed (Fig. 2A). As shown in Figure $2 \mathrm{~B}$, wortmannin induces cell death in the presence of serum and enhances apoptosis induced by MycER activation. The Ratla (MycER/Bcl-2) cells, however, were refractory to wortmannin treatment (Figure 2C,D).

Quantitative analysis showed a 3- to 4-fold increase in the percentage of apoptotic Ratla (MycER) cells after treatment with $200 \mathrm{nM}$ to $2 \mu \mathrm{M}$ wortmannin for $4 \mathrm{hr}$ in the presence of $5 \%$ FCS regardless of MycER activity (Fig. 2D), and similar results were obtained with Ratla (MycER/V12H-Ras), (MycERARaf), and (MycER/v-Src cells) (data not shown). Acceleration of cell death was detected at concentrations as low as $20 \mathrm{~nm}$ (Fig. 2D). The concentrations of wortmannin that accelerated apoptosis in these experiments have been reported to be specific for inhibition of PI 3-kinase and do not inhibit PI 4-kinase, PKA, PKC, or PKG /Ui et al. 1995; Wymann et al. 1996). These results, therefore, suggest that either PI 3 -kinase or other members of this family of proteins (Hunter 1995) that are inhibited by wortmannin are required to deliver a survival signal mediated by serum and growth factors.

\section{A downstream effector of PI 3-kinase, the serine/threonine kinase Akt/PKB, transduces a survival signal that is correlated with its kinase activity}

One downstream effector of PI 3-kinase is the serine/ threonine kinase $\mathrm{Akt} / \mathrm{PKB}$, the cellular homolog of the v-Akt oncoprotein (Bellacosa et al. 1991; Burgering and Coffer 1995; Franke et al. 1995). v-Akt is identical to its cellular homolog, c-Akt, except that it is fused in-frame to the viral Gag protein, targeting Akt to the plasma
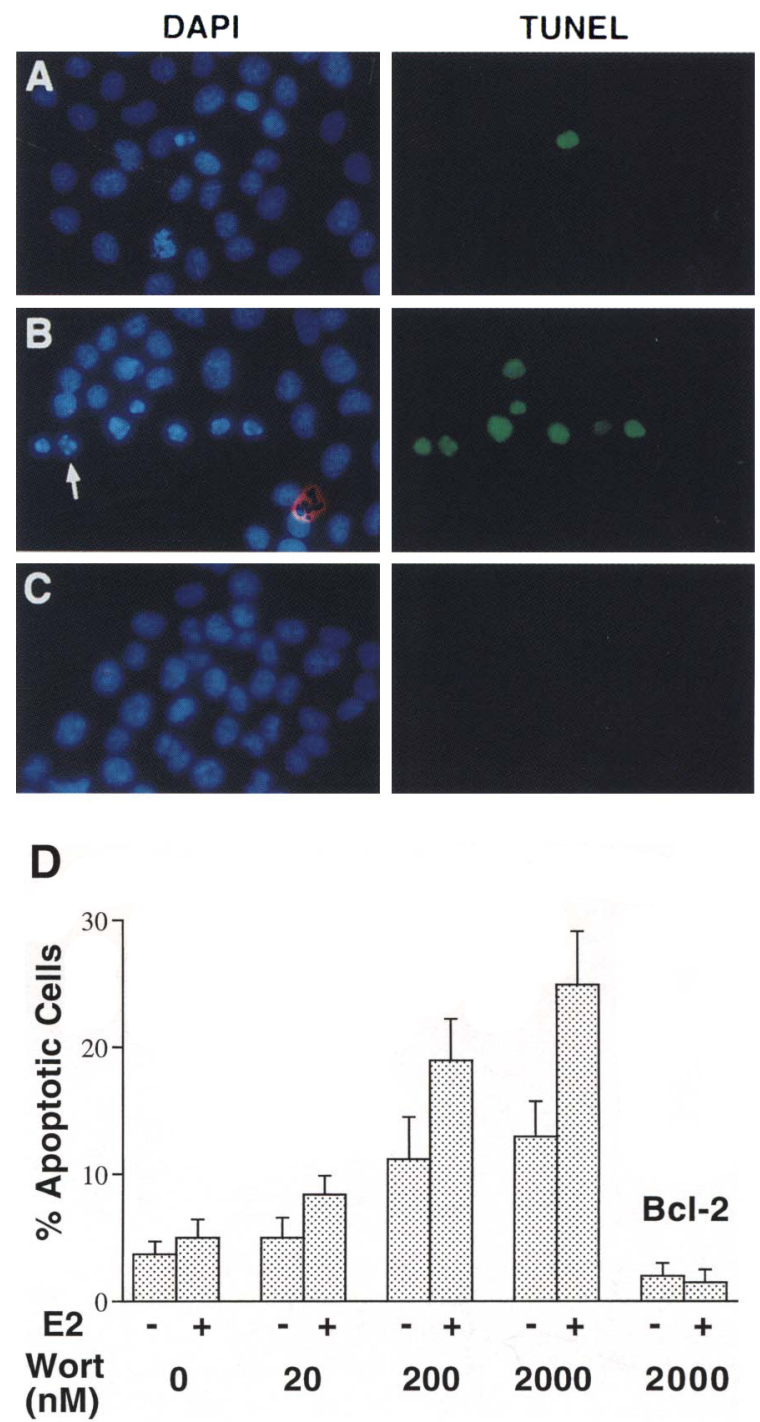

Figure 2. Wortmannin overrides serum-mediated survival and accelerates apoptosis. Representative fields of DAPI (left) and TUNEL (right) staining $4 \mathrm{hr}$ following MycER activation in the absence or presence of wortmannin. Nuclei scored positive by TUNEL have condensed chromatin as shown by DAPI staining. (A) Activation of MycER in the presence of $5 \%$ FCS and the absence of wortmannin. Only one apoptotic cell was observed in this representative field. $\{B \mid$ Activation of MycER in the presence of $5 \%$ FCS and $200 \mathrm{nM}$ wortmannin in Ratla (MycER) cells. Apoptosis is accelerated by treatment with wortmannin. A typical apoptotic nucleus at a late stage of apoptosis and with condensed chromatin is indicated by the arrow. $(C)$ Activation of MycER in the presence of $5 \%$ FCS and wortmannin in Ratla (MycER/Bcl-2) cells. Bcl-2 blocks acceleration of apoptosis by wortmannin. (D) Quantitation of DAPI-stained apoptotic Rat1a (MycER) or Ratla (MycER/Bcl-2) cells treated with varying concentrations of wortmannin in the presence of $5 \%$ FCS and with or without MycER activation ( \pm E2). Bars represent means of four independent experiments $( \pm$ S.E.). Cells were treated (as described above) with DMSO or varying concentrations of wortmannin and assayed by DAPI staining $4 \mathrm{hr}$ following activation of MycER. 
membrane (Bellacosa et al. 1991). This targeting activates Akt (Bellacosa et al. 1991; Burgering and Coffer 1995; Franke et al. 1995), yielding a kinase activity in the absence of serum almost as high as c-Akt kinase activity in $20 \%$ FCS (see below).

Akt is activated preferentially by growth factors that promote survival (Harrington et al. 1994; Franke et al. 1995), and, as shown above (Fig. 2), PI-3 kinase inhibition by wortmannin resulted in apoptosis in the presence of serum. We therefore tested the possibility that Akt is involved in mediating the survival signal transduced by serum and growth factors. Akt and v-Akt were introduced into Ratla (MycER) cells by retroviral infection. A second activated form of Akt with the Src myristoylation signal fused in-frame to the c-Akt coding sequence (MyrAkt) (Franke et al. 1995) was also introduced into the cells. Several hundred clones expressing c-Akt, vAkt, and MyrAkt were pooled and maintained as cell lines. Individual clones expressing v-Akt were also isolated and maintained as cell lines. The expression of cAkt, v-Akt, MyrAkt, and MycER in the established cell lines was verified by Western analysis (Fig. 3A). Cells were then tested for susceptibility to apoptosis in $0.5 \%$ FCS and $1 \mu \mathrm{M}$ E2. MyrAkt and v-Akt significantly protected cells from apoptosis induced by serum withdrawal and MycER activation, whereas minimal protection from cell death was observed in the c-Akt-overexpressing cells (Fig. 3B).

To assess whether Akt is associated with general inhibition of apoptosis induced by serum withdrawal, wild-type Ratla cells were also examined. Ratla cells exhibit a significant level of programmed cell death when plated at low density in the absence of serum $10 \%$ FCS). Both MyrAkt and v-Akt protected Ratla cells from apoptosis following serum withdrawal, whereas ectopic expression of c-Akt elicited only modest protection (Fig. $3 \mathrm{C}$. The difference in the abilities of the various Akt forms to elicit survival is correlated with their kinase activities (Fig. 3D). Ratla cells expressing c-Akt have a basal kinase level slightly higher than that of control Ratla cells, and they demonstrated only minimal protection from apoptosis. However, cells expressing v-Akt or MyrAkt have further elevated kinase activities (2- and 4-fold, respectively) and demonstrated a proportionally higher level of protection from apoptosis (Fig. 3C,D).

To verify further that the ability of Akt to deliver a survival signal is correlated with its kinase activity, we assayed Akt kinase activity in lysates of c-Akt and v-Aktoverexpressing cells in the absence of serum and upon serum stimulation (Datta et al. 1995; Franke et al. 1995). In Ratla (c-Akt) cells, Akt kinase activity was dramatically induced 15 min after addition of $20 \%$ FCS to serum-deprived cells and was inhibited completely by wortmannin (Fig. 4A). This activity peaked 15-30 min after addition of serum and declined by $3 \mathrm{hr}$ to a basal level of activity observed in proliferating cells (data not shown). In contrast to c-Akt-overexpressing cells, Ratla ( $\mathrm{v}$-Akt) cells exhibited a higher basal kinase activity in $0 \%$ FCS that was only slightly lower than that of c-Akt expressing cells $15 \mathrm{~min}$ following addition of $20 \%$ FCS (Fig. 4A).
The Akt kinase activity of Ratla (v-Akt) cells can be superinduced by $20 \%$ FCS. This induction was reduced by wortmannin to levels similar to that observed in $0 \%$ serum (Fig. 4A). Because the v-Akt kinase activity in $0 \%$ serum was comparable to that in the presence of serum and wortmannin, we tested whether v-Akt would still protect cells when PI 3-kinase activity was blocked. As shown in Figure 4B, cells expressing v-Akt are resistant to wortmannin-induced cell death to the same extent as they are to serum deprivation-induced cell death. Thus, in conditions of low Akt kinase activity (serum starvation or wortmannin treatment), cells are susceptible to apoptosis, whereas in conditions of higher kinase activity (presence of serum or activated $\mathrm{Akt}$ ) cells are resistant.

To demonstrate that the endogenous Akt delivers the survival signal mediated by grow th factors, we employed a mutant of Akt that contains a point mutation in the ATP binding site (Akt K179M) that was shown previously to abolish its kinase activity (Franke et al. 1995). This kinase-inactive Akt mutant, which previously has been suggested to act in a dominant-negative manner (Kohn et al. 1995), was toxic to Ratla cells and could not be stably expressed. Low levels of the kinase-inactive c-Akt could be expressed, however, in Ratla cells overexpressing Bcl-2 [Rat1a (Bcl-2) cells] (Fig. 5B, lane 2), but decreased the ability of $\mathrm{Bcl}-2$ to inhibit cell death upon serum deprivation (Fig. 5C), and accelerated apoptosis in low serum concentrations (Fig. 5C,D). Although Bcl-2 is able to protect cells from wortmannin treatment for $4 \mathrm{hr}$ in the presence of serum (Fig. 2B), it cannot override the effect of the Akt kinase-deficient mutant for a prolonged period of serum deprivation or at low serum concentrations (Fig. 5C,D). Thus, it is likely that the toxicity of the kinase-deficient mutant is a result of inhibition of endogenous Akt, further supporting our observation that Akt kinase activity is required for the anti-apoptotic signaling pathway induced by growth factors and serum.

The acceleration of apoptosis by the kinase-deficient Akt that was observed in the absence of serum (Fig. 5D) is possibly a result of inhibition of endogenous basal Akt kinase activity. This basal level of Akt kinase activity may reflect intracellular levels of $\operatorname{Ptdlns}(3) \mathrm{P}$, a product of PI 3-kinase that was shown to activate Akt by binding to its pleckstrin homology (PH) domain (Franke et al. 1995) but whose level does not change significantly upon growth factor stimulation (Kapeller and Cantley 1994).

Taken together, these results strongly suggest that Akt is able to deliver a survival signal induced by growth factors and serum, and that this ability is dependent on its kinase activity. In addition, the ability of activated Akt to override the apoptotic effect of wortmannin in the presence of serum suggests that wortmannin induces apoptosis by inhibiting the ability of PI 3-kinase to activate Akt.

Akt does not elevate Bcl-2 and $B c l-X_{L}$ expression but inhibits PARP protease activity

The apoptotic pathway in mammalian cells, as in C. elegans, is coordinated by negative regulators that are 

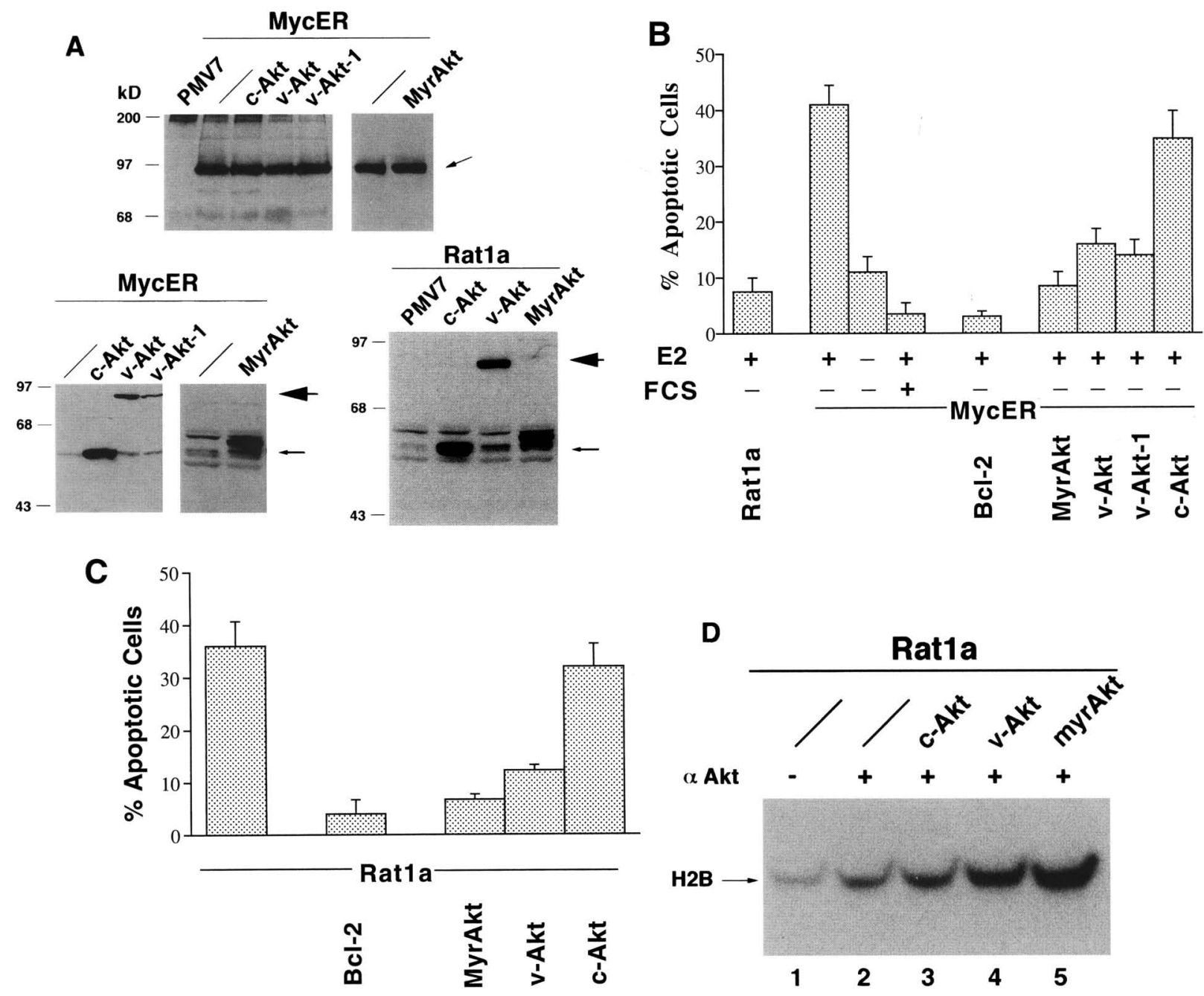

D

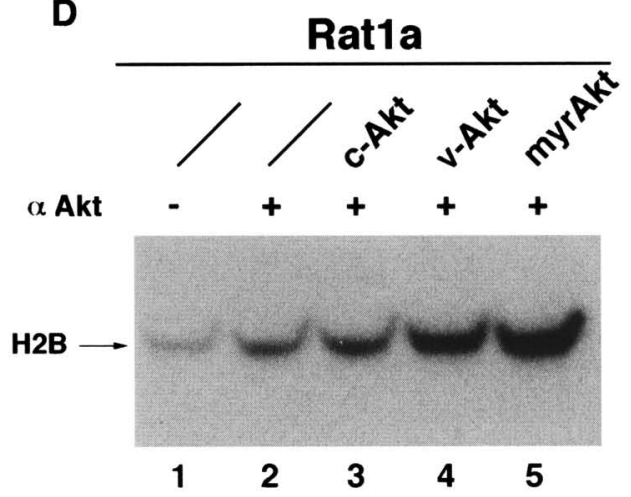

Figure 3. Activated Akt protects from Myc and non-Myc-accelerated apoptosis. (A) Immunoblot analysis of ectopically expressed proteins in Ratla (MycER) and parental Ratla cells. (Top) Expression of MycER; arrow indicates migration of MycER. (Bottom) Expression of Akt proteins; v-Akt and MyrAkt/c-Akt are indicated by large and small arrows, respectively. Molecular size markers (in $\mathrm{kD}$ / are indicated. The reduced mobility of the MyrAkt is a result of HA epitope tag in this construct. Expression in a pool of v-Akt expressing cells and in an individual clone (v-Akt-1) is shown. $(B)$ Percentage of apoptotic cells scored by DAPI staining of Ratla (MycER) nuclei $16 \mathrm{hr}$ following MycER activation ( \pm E2) in the presence of $10 \%$ FCS $(+)$ or $0.5 \%$ FCS $(-)$. The data presented here and in Fig. $1 \mathrm{C}$ were obtained simultaneously. $|C|$ Percentage of apoptotic cells scored by DAPI staining of Ratla nuclei $16 \mathrm{hr}$ following incubation in $0 \%$ FCS. Ratla cells were plated at 50,000 cells $/ 3-\mathrm{cm}$-diam. plate and stained with DAPI. (D) Basal Akt kinase activity of Ratla cells (lanes 1,2) and Ratla cells expressing the indicated Akt proteins measured by histone 2B (H2B) phosphorylation. Cells were starved in $0 \%$ FCS overnight. Extracts were then immunoprecipitated with rabbit IgG (lane 1) or $\alpha$-Akt (lanes 2-5). Akt kinase assay was performed, with the immunoprecipitants and histone $\mathrm{H} 2 \mathrm{~B}$ used as a substrate, and was quantitated with the AMBIS system.

members of the Bcl-2 family that promote survival, and by positive regulators that are the members of the Ced3/ ICE family of proteases that can actively kill cells. Thus, potential mechanisms by which Akt promotes survival may include activation of the Bcl-2 family members or/ and inactivation of the Ced3/ICE family of proteases (Takahashi and Earnshaw 1996). As shown in Figure 6, A and $B$, we did not observe any change in the steady-state levels of $\mathrm{Bcl}-2$ or $\mathrm{Bcl}-\mathrm{X}_{\mathrm{L}}$ after serum deprivation regardless of activated Akt expression. We then examined the activity of the PARP protease (Tewari et al. 1995), (Fig. $6 \mathrm{C})$, which can specifically cleave PARP to yield an 85-
$\mathrm{kD}$ fragment and has a similar substrate specificity as the C. elegans Ced3 protease (Xue et al. 1996). We found that upon serum withdrawal, caspase activity that cleaves PARP is induced (Fig. 6C, lanes 1-6,13), whereas in cells that constitutively express activated Akt the induction of this activity is inhibited (Fig. 6C, lanes 7-12,14). Similar results were obtained when a fluorogenic substrate DEVD-AFC, which mimics a site on PARP, was used as a cleavage substrate for cell lysates made at different time points following induction of apoptosis (Fig. 6D,E). By using a fluorogenic substrate, YVAD-AFC, which mimics a site on pro-IL-1 $\beta$, we found 


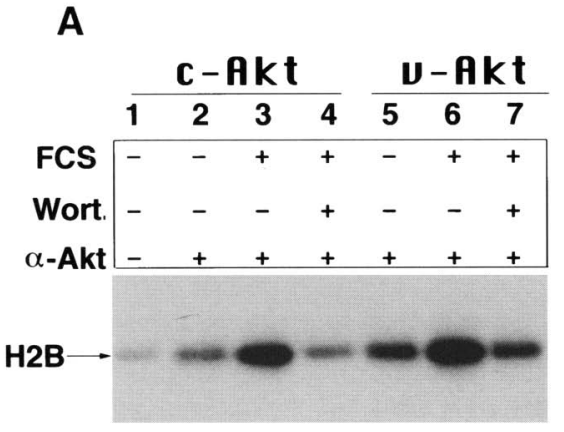

\section{B}

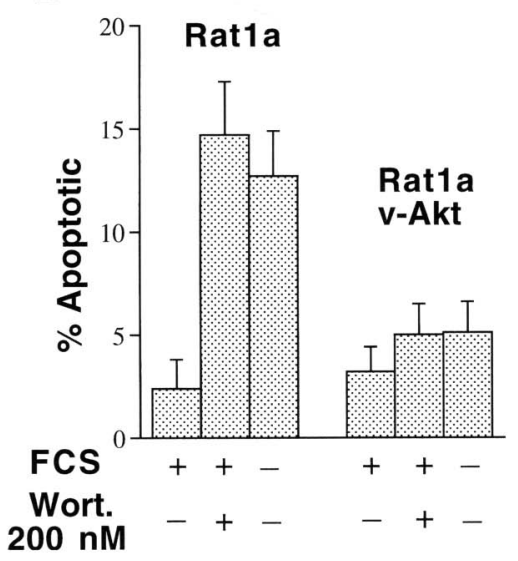

Figure 4. Akt-mediated survival signal is dependent on Akt kinase activity. $(A)$ Akt kinase activity of c-Akt- and v-Akt-overexpressing Ratla cells in various cell culture conditions. Cells were starved overnight in $0 \%$ FCS, then rinsed twice and placed in $20 \%$ serum $( \pm$ FCS $)$ with or without cotreatment of $200 \mathrm{nM}$ wortmannin ( \pm Wort.). After 15 min, cell lysates were incubated with rabbit IgG $(-\alpha$-Akt $)$ or anti-Akt antibodies $1+$ $\alpha$-Akt) and Akt kinase activity was measured in the immunoprecipitants. A representative kinase assay is shown. (B) Percent apoptotic Ratla cells and Ratla (v-Akt) cells following serum starvation and wortmannin treatment. Cells were starved overnight in $0.5 \%$ FCS then rinsed twice and placed in $0 \%$ serum $\pm 200 \mathrm{~nm}$ wortmannin. FCS $(5 \%)$ was added after $30 \mathrm{~min}$, and after an additional $3.5 \mathrm{hr}$ nuclei were DAPI stained. Bars represent averages $( \pm$ S.E.) of four independent experiments. no induction of this enzymatic activity following serum deprivation (Fig. 6D,E). The induction of caspase activity that cleaves PARP was more pronounced in cells that were deprived of serum in conjunction with MycER activation, but the activity was also observed in Ratla cells deprived of serum (Fig. 6C, lanes 13,14; Fig. 6E). The inhibition of the caspase activity that cleaves PARP by activated Akt is only slightly less than the inhibition observed by ectopically expressed Bcl-2 (Fig. 6D). We therefore concluded that a caspase activity that cleaves PARP [which is likely to be mediated by CPP32 (Tewari et al. 1995)], and not ICE-like activity, is induced after serum deprivation. This protease activity is dramatically inhibited by activated Akt and by Bcl-2.

\section{Discussion}

The anti-apoptotic properties of certain growth factors and cytokines are not necessarily coupled to cellular proliferation (Fairbairn et al. 1993; Raff et al. 1993; Harrington et al. 1994). Here we show that the Ras/Raf and Src signaling pathways, although mitogenic, are not sufficient to promote survival upon growth factor withdrawal. However, although signal transduction through the PI 3-kinase/Akt pathway can activate a survival signal, we found that activated Akt is not sufficient to induce serum-deprived cells to enter the cell cycle, as measured by bromodeoxyuridine (BrdU) incorporation (S.G. Kennedy and N. Hay, unpubl.). These results may explain why some mitogenic growth factors, such as EGF, which are not effective inducers of the PI 3-kinase/Akt signaling pathway, are also poor survival factors in cells of mesenchymal origin (Harrington et al. 1994; Franke et al. 1995).

The inhibition of apoptosis elicited by activated Akt is similar to or higher than the level of inhibition promoted by IGF-I, insulin, and PDGF (Harrington et al. 1994). How- ever, these anti-apoptotic effects are about twofold lower than the serum-mediated block of apoptosis, suggesting that serum may activate multiple signaling pathways that inhibit apoptosis. These may include distinct PI 3-kinases and Akt proteins that are induced by multiple extracellular signals or other unidentified pathways. These signals may also include activation of atypical PKCs and/or NF- $\mathrm{kB}$ (Diaz-Meco et al. 1996; Liu et al. 1996).

It was shown previously that activation of Akt is not induced by stably expressed activated Ras and is not affected in cells that express dominant-negative Raf or cells that are deficient in Src (Burgering and Coffer 1995; Franke et al. 1995). These results are consistent with the observations presented here. However, both Ras and Src have been shown to activate PI 3-kinase (Pleiman et al. 1994; Rodriguez-Viciana et al. 1994). One possible explanation for this apparent paradox is that the levels of stably expressed activated Ras or Src, although able to transform cells in the presence of serum, are not sufficient to activate the PI 3-kinase/Akt signaling pathway in the absence of serum. However, transient high-level expression of both activated Ras and Src activates Akt (Datta et al. 1996). Another possible explanation is that the ability of Ras and Src to activate PI 3-kinase is cell type-specific.

The ability of activated Akt to promote survival is not limited to fibroblasts, as we found that activated Akt protects PC12 pheochromocytoma cells from undergoing apoptosis upon growth factor withdrawal (S.G. Kennedy and N. Hay, unpubl.) and a neuronal cell line from undergoing apoptosis following induction of differentiation (E. Eves, A. Bellacosa, P.N. Tsichlis, M.R. Rosner, and N. Hay, unpubl.). However, Akt might not be a general inhibitor of apoptosis as we have found that activated Akt does not effectively block etoposide- or UVinduced apoptosis in the presence of serum (S.G. Kennedy and N. Hay, unpubl.). 

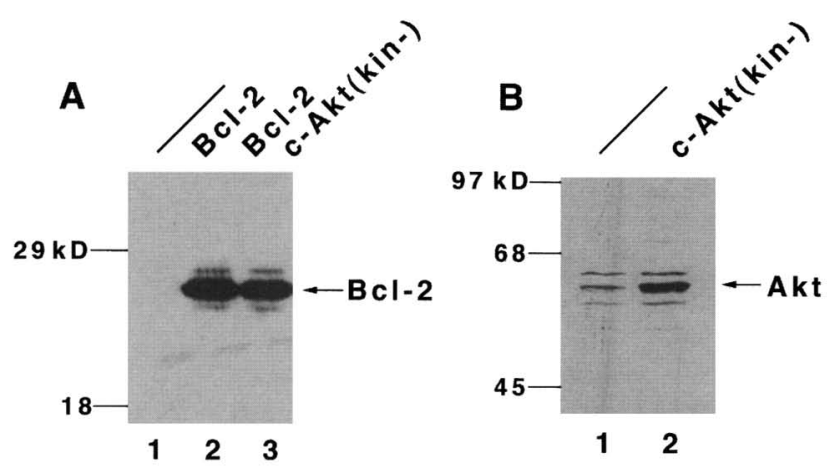

C

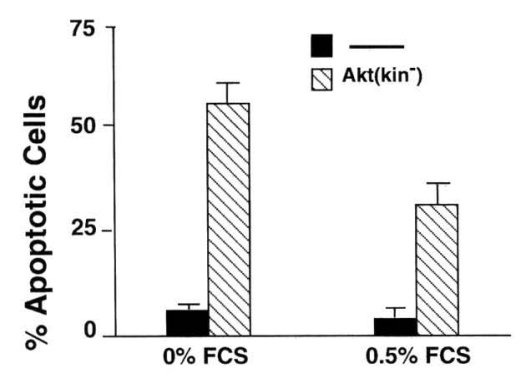

D

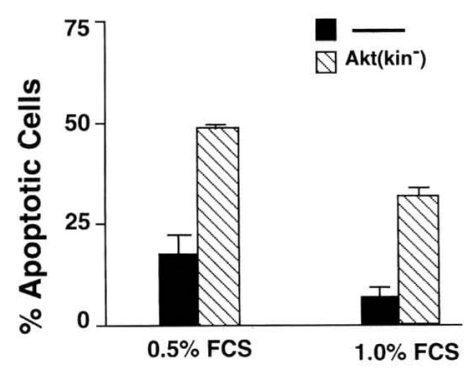

Figure 5. A dominant-negative Akt mutant containing a point mutation in the ATP binding site accelerates apoptosis. $|A| \mathrm{Ex}$ pression levels of ectopically expressed human Bcl-2 in Ratla (Bcl-2) and Rat1a (Bcl-2/Akt kin-). (Lane 1) Ratla cells; (lane 2) Ratla(Bcl-2) cells; lane (3) Ratla (Bcl-2/Akt kin-) cells. (B) Expression level of ectopically expressed Akt K179M in Rat 1a (Bcl2) cells. (Lane 1) Ratla (Bcl-2) cells; (lane 2) Ratla (Bcl-2/Akt kin-/ cells. Percent apoptotic Ratla (Bcl-2) and Ratla (Bcl-2/Akt kin- $\}$ cells as measured by DAPI staining after $30 \mathrm{hr}(C)$ or $60 \mathrm{hr}$ (D). Cells were seeded as described in Fig. $3 \mathrm{C}$ and then in $0 \%$, $0.5 \%$, or $1.0 \%$ FCS for $30 \mathrm{hr}$ or $60 \mathrm{hr}$. Bars represent averages ( \pm S.E.) of three independent experiments.

\section{How does Akt promote survival?}

Two major components play a role in the control of the cell death pathway both in C. elegans and in mammals: the Bcl-2 family members, which block apoptosis, and the Ced-3/ICE-like protease family, which executes the apoptotic pathway. The PI 3-kinase/Akt signaling pathway might be predicted to act through modulation of Bcl-2 expression, and it was shown that expression of Bcl-2 is induced by IL-2 (Miyazaki et al. 1995). However, we did not detect any significant changes in the steady- state levels of Bcl-2 and Bcl- $\mathrm{X}_{\mathbf{L}}$ in Ratla cells that constitutively express an activated Akt. In addition, we did not detect any changes in the steady-state level of Bax following serum withdrawal or upon activation of Akt (S.G. Kennedy and N. Hay, unpubl.). It is possible that, in hemopoietic cells, the PI 3-kinase/Akt pathway can induce Bcl-2 expression. This could be an indirect effect of an autocrine loop mediated by PI 3-kinase/Akt that induces secretion of cytokines such as IL-2, which will then elicit both proliferation and survival. We found, however, that the ability of Akt to mediate survival was associated with the inhibition of Ced-3/ICE-like protease(s) that specifically cleave PARP. This cleavage activity is likely to be mediated by CPP32, which recognizes the peptide sequence DEVD (Tewari et al. 1995). Interestingly, upon serum withdrawal, unlike Fas-mediated apoptosis (Enari et al. 1996), the activity of PARP protease is induced without any detectable induction of ICElike activity that can specifically cleave pro-IL- $1 \beta$ and recognizes the peptide sequence YVAD. We concluded that, at least in fibroblasts, growth factors and Akt block CPP32-like activity (caspase activity that cleaves PARP) and promote survival by a mechanism independent of changes in Bcl-2 or Bcl- $\mathrm{X}_{\mathrm{L}}$ expression. We cannot completely exclude the possibility that an Akt signaling pathway, although not altering the expression of Bcl-2 and $\mathrm{Bcl}-\mathrm{X}_{\mathrm{L}}$ may render them hyperactive by a posttranslational mechanism (Uhlman et al. 1996). Further support for a possible interplay between Bcl-2 activity and Akt signaling is suggested by our observations that Bcl-2 inhibits wortmannin-induced cell death and that a dominant-negative Akt antagonizes the ability of Bcl-2 to promote survival.

Because there are multiple downstream effectors of Akt, it is not completely clear how the survival signal is transduced. It is possible that multiple pathways contribute synergistically to the anti-apoptotic function of Akt. The inhibition of Ced-3/ICE-like activities /caspase activity that cleaves PARP/ could rely on known potential downstream effectors of Akt or an unknown pathway. A model illustrating multiple potential mechanisms by which Akt delivers a survival signal is shown in Figure 7.

One potential downstream effector is TOR/FRAP (target of rapamycin/ㅌKBP rapamycin-âssociated protein) (Brown and Schreiber 1996). TOR is conserved between yeast and man, and TOR kinase activity can be inactivated by the drug rapamycin (Barbet et al. 1996; Kunz and Hall 1993). Genetic experiments in yeast as well as experiments employing rapamycin in mammalian cells have shown that deletion of TOR or inactivation by rapamycin leads to $G_{1}$ arrest (Barbet et al. 1996). However, rapamycin was also shown to accelerate apoptosis in several cell systems subjected to different types of insult (Shi et al. 1995). Thus, depending on the level of the insult, the inactivation of TOR may mediate either growth arrest or apoptosis, similar to activation of p53 (Bates and Voudsen 1996). It is therefore possible that constitutive activation of TOR (presumably by an activated $\mathrm{Akt}$ ) is analogous to inactivation or deletion of 
A

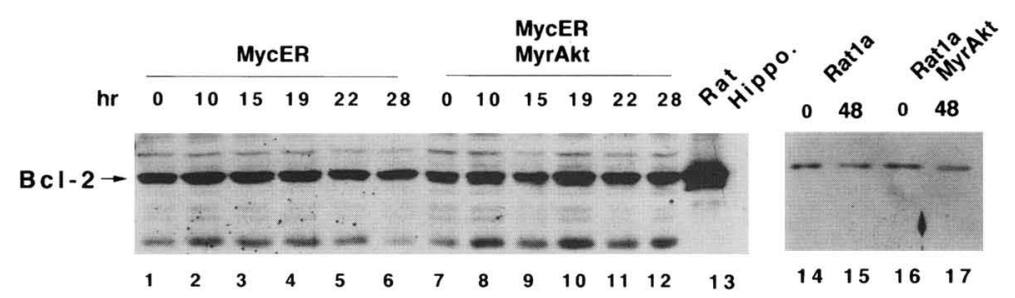

B

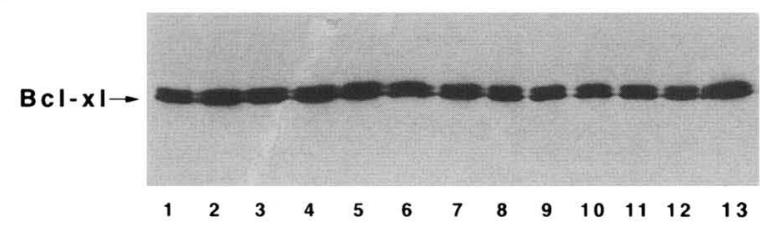

C

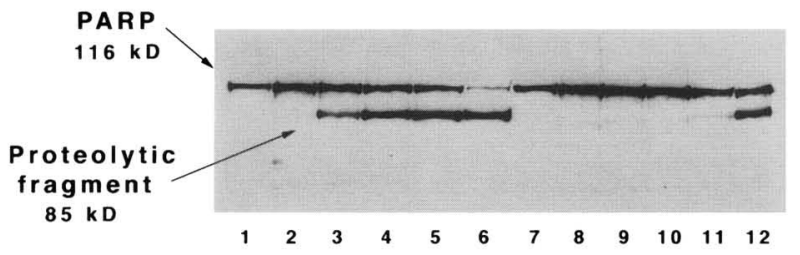

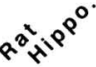
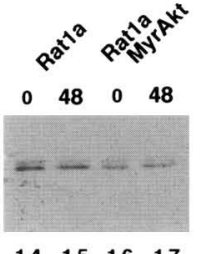

$14 \quad 15 \quad 16 \quad 17$

D

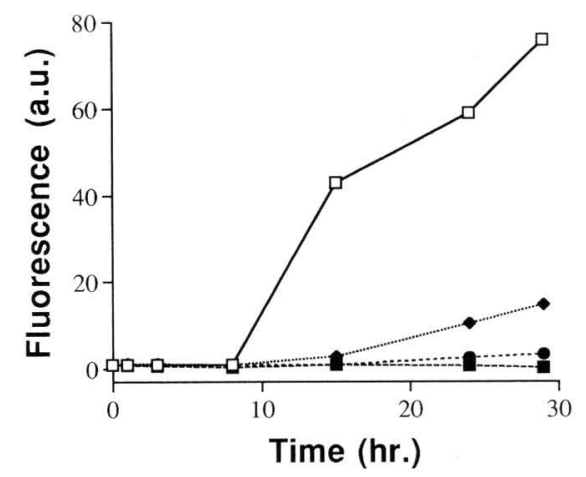

E

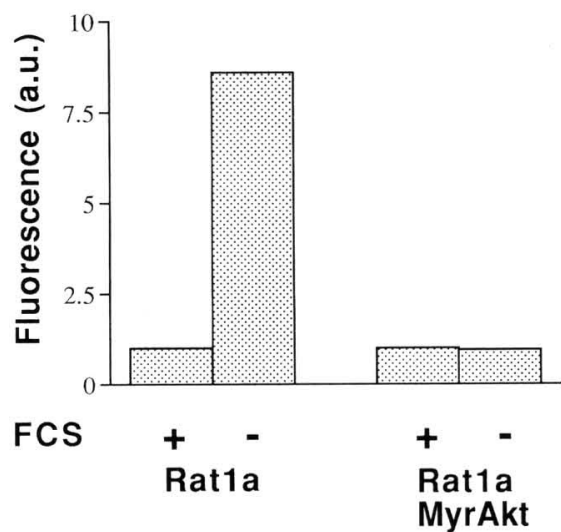

Figure 6. Akt does not elevate the expression of $\mathrm{Bcl}-2$ or $\mathrm{Bcl}-\mathrm{X}_{\mathrm{L}}$, but inhibits activation of a PARP protease upon serum withdrawal. Rat1a(MycER) and Rat1a (MycER/MyrAkt) cells were serum-starved (0.5\% FCS) and treated with $1 \mu \mathrm{M}$ E2 for the indicated times. Rat la and Rat la(MyrAkt) cells were serum-starved ( $\%$ FCS) for $48 \mathrm{hr}$. (A) Immunoblot analysis of Bcl-2 expression. Expression of Bcl-2 in Rat1a(MycER) cells following serum withdrawal and activation of Myc (lanes 1-6). Expression of Bcl-2 in Ratla (MycER/MyrAkt) cells following serum withdrawal and activation of Myc (lanes 7-12). Bcl-2 expression in Rat1a and in Rat1a(MyrAkt) cells following serum withdrawal (lanes 14-17). Extract from rat hippocampal neurons was used as a control for the endogenous rat Bcl-2 protein (lane 13). (B) Immunoblot analysis of Bcl- $\mathrm{X}_{\mathrm{L}}$ expression. Expression of Bcl- $\mathrm{X}_{\mathrm{L}}$ in Ratla(MycER) cells following serum withdrawal and activation of Myc (lanes 1-6). Expression of Bcl- $\mathrm{X}_{\mathrm{L}}$ in Ratla (MycER/MyrAkt) cells following serum withdrawal and activation of Myc (lanes 7-12). Bcl- $\mathrm{X}_{\mathrm{L}}$ expression in Ratla and in Ratla(MyrAkt) cells following serum withdrawal (lanes 14-17). Extract from rat hippocampal neurons was used as a control for the endogenous rat $\mathrm{Bcl}-\mathrm{X}_{\mathrm{L}}$ protein (lane 13). (C) Immunoblot analysis of PARP cleavage. PARP cleavage in extracts made from cells treated as described in $A$ and $B$ (lanes 1-12). PARP cleavage in Ratla and Ratla(MyrAkt) $48 \mathrm{hr}$ following serum withdrawal (lanes 13,14$)$. The full-length PARP $(116 \mathrm{kD})$ and its proteolytic fragment $(85 \mathrm{kD})$ are indicated by arrows. $(D)$ Kinetics of CPP32-like and ICE-like protease activity in Ratla cell lines with DEVD-AFC (MycER, $\square$; MycER/MyrAkt, $\bullet$; and MycER/Bcl-2, 9 ) and Rat1 cell line MycER with YVAD-AFC ( $\mathbf{D}$ ) at different time points following serum withdrawal. (E) Activity of CPP32-like protease in Ratla and Ratla (MyrAkt) cell lysates extracted after $48 \mathrm{hr}$ in $0 \%$ serum.

p53. Alternatively (or additionally), apoptosis may be inhibited by acceleration of protein translation, which can be mediated by the ability of Akt, either directly or in conjunction with TOR, to activate p70 S6-kinase or/and to inhibit 4E-BP1 (Burgering and Coffer 1995; Beretta et al. 1996). The activation of p70 S6-kinase by Akt might not be sufficient, however, to promote survival because we found that a dominant-negative Akt inhibited S6kinase activity by only $30 \%$ (S.D. Conzen, S.G. Kennedy, and N. Hay, unpubl.), whereas the effect of the dominant-negative Akt on apoptosis was much more pronounced. Further experiments are required to verify this hypothesis and to identify downstream targets for this enhanced translation.

Another downstream effector of Akt/PKB is glycogen synthetase kinase 3 (GSK-3) (Cross et al. 1995). GSK-3 activity is inhibited by growth factors and by Akt (Welsh et al. 1994; Cross et al. 1995). GSK-3 was also shown to play a role in cell fate determination in both invertebrates and vertebrates (Briscoe and Firtel 1995). Whether and how GSK-3 activity is associated with programmed cell death remains to be determined. In adult tissues, it is possible that activation of GSK-3 leads to activation of the adenomatous polyposis coli (APC) protein, which 


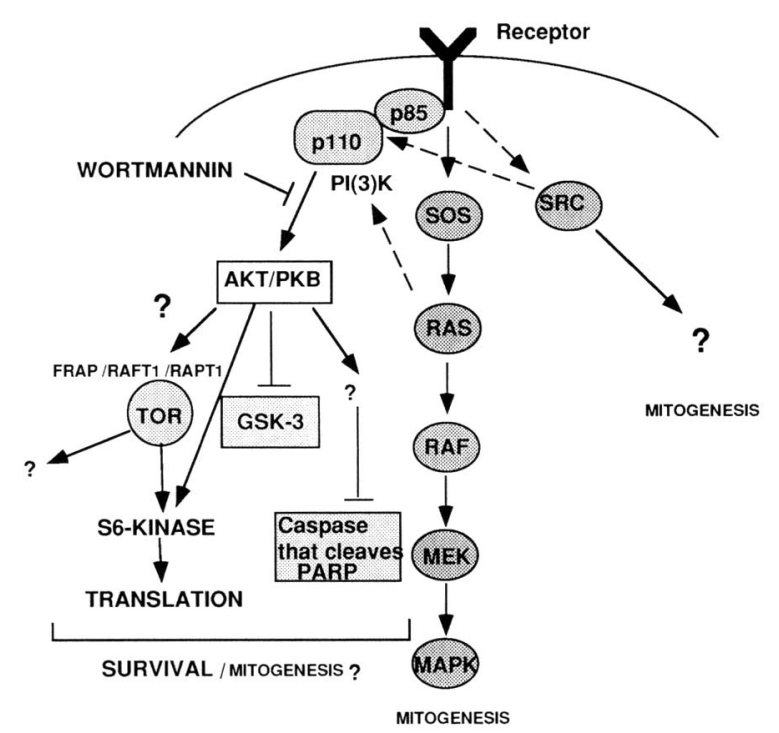

Figure 7. Model illustrating paths leading from growth factor receptor to mitogenesis and survival pathways. According to this model, activation of Ras and Src will lead mainly to mitogenesis, whereas activation of Akt will lead to survival. The ability of Akt to mediate survival is likely to be dependent on downstream effectors such as $\mathrm{p} 70$ S6-kinase and protein translation, activation of FRAP/TOR, and inhibition of GSK-3. According to this model, if TOR can be constitutively activated by Akt, it will promote survival in a manner analogous to inactivation of p53 (for more details see Discussion). These downstream effectors of Akt or other independent Akt-induced activity may lead to inhibition of the caspase activity that cleaves PARP.

may then accelerate apoptosis by degradation of $\beta$-catenin and inhibition of adhesion. This hypothesis is based on recent observations that placed APC downstream of GSK-3 and upstream of $\beta$-catenin (Matsumine et al. 1996; Peifer 1996; Rubinfeld et al. 1996), and on a recent report that showed that ectopically expressed wild-type APC accelerates apoptosis (Morin et al. 1996). Accordingly, it is feasible that inactivation of GSK-3 by Akt can contribute to the block of apoptosis. It is worth noting that increased adhesion by extracellular matrix has been shown to block ICE activity and inhibit apoptosis, and that fibronectin can inhibit apoptosis upon serum withdrawal (Boudreau et al. 1995; S.G. Kennedy and N. Hay, unpubl.). Interestingly, fibronectin has also been shown to activate Akt (W.G. King, M.D. Mattaliano, and J.S. Brugge, pers. comm.).

Stress-inducible kinases, which are modestly activated by wortmannin-induced inhibition of PI 3-kinase (Kharbanda et al. 1995; S.G. Kennedy and N. Hay, unpubl.), were shown previously to be associated with the induction of apoptosis (Verheij et al. 1996). Thus, the PI 3-kinase/Akt signaling pathway might inhibit activation of stress-inducible kinases and, in this manner, inhibit a pro-apoptotic signal from the stress kinases. However, we have not been able to detect any reduced activity of the stress-inducible kinase JNK in cells that constitu- tively express activated Akt, following UV irradiation (S.G. Kennedy and N. Hay, unpubl.).

We have demonstrated that the PI 3-kinase/Akt pathway has an important role in mediating cell survival. It is also possible that, by mediating survival, the PI 3-kinase/Akt pathway has a more global role in embryonic development and in longevity of adult tissues. A recent report has implicated a $C$. elegans homolog of $\mathrm{p} 110$, the catalytic subunit of the mammalian PI 3-kinase, as a mediator of longevity (Morris et al. 1996). Because Akt homologs were found in C. elegans (Waterston et al. 1992), it is conceivable that Akt also plays a role in longevity.

Further delineation of the PI 3-kinase/Akt signaling pathway may yield attractive targets for cancer chemotherapy. Many current chemotherapy regimens rely on induction of apoptosis (Thompson 1995), and many tumors have evaded cell death by activation of survival pathways such as Bcl-2 overexpression (Wagner et al. 1993) or by up-regulation of expression of potential survival factors (Christofori et al. 1994). Interestingly, Akt has been shown to be overexpressed in some human tumors (Staal 1987; Bellacosa et al. 1995). Specific inhibitors of kinases in these survival pathways may be therapeutic by themselves or, if used in combination with current chemotherapy modalities, may enhance tumor cell sensitivity. Our findings suggest that interfering with the Akt-mediated survival signal, by a dominantnegative Akt mutant, abrogates both serum- and growth factor-mediated survival and survival induced by Bcl-2 overexpression. Similarly, specific activators of this pathway would be expected to promote cell survival and might potentially be used for treatment of degenerative diseases that result from inappropriately increased cell death.

\section{Materials and methods}

\section{Cell culture and viral infection}

Cell culture, retrovirus stock production by transient transfection of retroviral vectors into BOSC23 cells, and retroviral infection were performed as described previously (Wagner et al. 1994). The retroviral vectors used were pMV12 for MycER, pMV7 or pMV12 for Bcl-2 (Wagner et al. 1993), pZIPNeo for V12H-Ras (Yao and Cooper 1995), pLNC for $\Delta$ Raf-1 (Samuels et al. 1993), pMX2122 for v-Src (gift of M. McMahon, DNAX, Palo Alto, CA), pLXSN for v-Akt and c-Akt, and SR- $\alpha$ for MyrAkt (Franke et al. 1995).

\section{Protein analysis}

Total cell protein from $1 \times 10^{5}$ cells was denatured in $2 \times$ Laemmli buffer. Extracts were electrophoresed in $8 \%$ or $10 \%$ SDS-polyacrylamide gels. Following electrophoresis, proteins were blotted onto nitrocellulose membranes by semidry transfer and incubated with the following primary antibodies: $\mathrm{H} 222$ rat monoclonal anti-ER (gift of G. Greene, University of Chicago, IL), rabbit polyclonal anti-Bcl-2 (Santa Cruz n-19), mouse monoclonal anti-v-Src (LA074, Quality Biotech), rabbit polyclonal anti-Raf-1 (C-12, Santa Cruz Biotech, Inc.), anti-H-Ras (259, Santa Cruz Biotech, Inc.), anti-c-Akt (Franke et al. 1995), 
and mouse monoclonal anti-PARP c2-10 (gift of G. Poirier, Sante-foy, Quebec, Canada). For the PARP protease assay cells were resuspended in lysis buffer containing $6 \mathrm{M}$ urea and were sonicated before loading on gel.

\section{Soft agarose assays}

Five thousand cells were plated in $0.35 \%$ Sea Plaque agarose on top of a layer of $0.7 \%$ Sea Plaque agarose in DMEM with $10 \%$ FCS. Colonies were allowed to grow for 24 days. Plates were projected onto a white board and the number of colonies $>0.5$ $\mathrm{mm}$ in diameter were counted.

\section{Apoptosis assays}

For DAPI staining, cells were seeded at $1.5 \times 10^{5}$ cells $/ 3-\mathrm{cm}$ diameter plate and allowed to grow in $10 \%$ FCS for $24 \mathrm{hr}$. Cells were rinsed once in PBS and $2 \mathrm{ml}$ of DMEM containing $0.5 \%$ FCS and $1 \mu \mathrm{M}$ of E2 was added; $2 \mathrm{ml}$ of DMEM without FCS was added to Ratla cells without MycER. After $16 \mathrm{hr}, 400 \mu \mathrm{l}$ of formaldehyde was added to each well for $30 \mathrm{~min}$. Cells were then rinsed with PBS and cold $0.1 \%$ Triton X-100/ $0.1 \%$ sodium citrate in PBS was added for 2 min. Cells were rinsed with PBS and $1 \mu \mathrm{M}$ DAPI in PBS was added for $1 \mathrm{~min}$. Cells were rinsed twice with PBS and air-dried. Ten microliters of mounting solution $(50 \%$ glycerol-TBS at $\mathrm{pH} 9.0$, and $1 \mathrm{mg} / \mathrm{ml}$ of phenylene diamine/ was added, overlaid with a coverslip, and sealed with nail polish. Three fields per plate containing a minimum of 100 cells were scored, using an ultraviolet microscope, for percentage of apoptotic cells. DAPI staining experiments described in Figures $1 \mathrm{C}$ and $3 \mathrm{~B}$ were performed simultaneously.

For PI/FDA staining, cells were seeded at 150,000 cells $/ 3-\mathrm{cm}$ diameter plate in $10 \% \mathrm{FCS}$ for $24 \mathrm{hr}$. Cells were rinsed once in PBS and $2 \mathrm{ml}$ of DMEM containing $0.5 \% \mathrm{FCS} \pm 1 \mu \mathrm{M}$ of E2 was added for $48 \mathrm{hr}$. Five hundred microliters of $10 \mu \mathrm{g} / \mathrm{ml}$ of FDA and $30 \mu \mathrm{g} / \mathrm{ml}$ of PI in PBS was added to each well. After $5 \mathrm{~min}$, cells were photographed under UV illumination. Each field contained a minimum of 200 cells. Slides were projected onto a white board and live (FDA stained) and dead (PI stained) cells were counted.

The TUNEL assay was a modification of the DAPI assay. Cells were seeded onto single well Costar glass slides. Following addition of $0.1 \%$ Triton X-100/0.1\% sodium citrate (see above), slides were rinsed twice with PBS. Slides were air-dried, then 50 $\mu$ of TUNEL solution (Boehringer Mannheim) was added. Slides were placed in a humidified chamber at $37^{\circ} \mathrm{C}$ for $1 \mathrm{hr}$, then rinsed twice with PBS and counterstained with $1 \mu \mathrm{M}$ DAPI in PBS. Slides were allowed to dry, mounted, and fixed as described above.

\section{Akt kinase assay}

Ratla cells $\left(3 \times 10^{5}\right)$ were plated on $6-\mathrm{cm}$ diameter plates and grown overnight, then starved overnight in $0 \%$ FCS. Immunoprecipitation and kinase assays were done according to Franke et al. \{1995). Protein concentration was determined by Bradford assay and equal amounts of protein were used for immunoprecipitation. Control immunoprecipitations were done with rabbit IgG pre-bound to protein $\mathrm{A} / \mathrm{G}$-agarose beads. Quantitation of phosphorylated $\mathrm{H} 2 \mathrm{~B}$ was determined by radio-imaging of dried gels on an AMBIS system.

In vitro assay for aspartase activity (ICE-like and CPP32-like activities)

Cells were seeded as described above for the apoptosis assays. Cells were rinsed in cold PBS and scraped into $1 \mathrm{ml}$ buffer of 25
mM HEPES (pH 7.5), 5 mM EDTA, 1 mM EGTA, $5 \mathrm{~mm} \mathrm{MgCl}_{2}, 5$ $\mathrm{mM}$ DTT, $10 \mu \mathrm{g} / \mathrm{ml}$ of pepstatin/leupeptin, and $1 \mathrm{mM}$ PMSF. Cells were sonicated on ice. Cell lysates were centrifuged for 30 $\min$ at $160,000 \mathrm{~g}$ and supernatants were stored at $-80^{\circ} \mathrm{C}$. Protein concentration was quantitated by Bradford assay. Lysates (10 $\mu \mathrm{g}$ of protein) in $1 \mathrm{ml}$ of $25 \mathrm{~mm}$ HEPES (pH 7.5), $10 \%$ sucrose, $0.1 \%$ CHAPS, and $10 \mathrm{~mm}$ DTT were incubated with fluorescently conjugated peptides DEVD-AFC $(15 \mu \mathrm{M})$ and YVAD-AFC $(25$ $\mu \mathrm{M})$ (Enzyme System Products, Dublin, CA) at $37^{\circ} \mathrm{C}$ for $30 \mathrm{~min}$. Fluorescence of cleaved peptides was quantified in a fluorometer (excitation $400 \mathrm{~nm}$, emission $505 \mathrm{~nm}$ ).

\section{Acknowledgments}

N.H. dedicates this paper to the memory of his father Benjamin Hay. We thank C. Palfrey for critical comments and valuable discussions; M. McMahon, S. Reeves, and G. Poirier for retroviral vectors and reagents; and W.G. King, M.D. Mattaliano, and J.S. Brugge for sharing results before publication. This work was supported by American Cancer Society grant CB-133 and in part by National Institutes of Health (NIH) grants CA58073 and CA66132 (N.H.). S.G.K. was supported by training grant GM07151. J.J. was supported by a grant from Ministerio de Educación y Ciencia of Spain and by NIH grant DA02121 to R. Miller. A.B. and P.N.T. were supported by NIH grant CA57436.

The publication costs of this article were defrayed in part by payment of page charges. This article must therefore be hereby marked "advertisement" in accordance with 18 USC section 1734 solely to indicate this fact.

\section{References}

Askew, D.S., J.N. Ihle, and J.L. Cleveland. 1993. Activation of apoptosis associated with enforced myc expression in myeloid progenitor cells is dominant to the suppression of apoptosis by interleukin-3 or erythropoietin. Blood 82: 20792087.

Barbet, N.C., U. Schneider, S.B. Helliwell, I. Stansfield, M.F. Tuite, and M.N. Hall. 1996. Tor controls translation initiation and early G1 progression in yeast. Mol. Biol. Cell 7: 2542.

Bates, S. and K.H. Voudsen. 1996. p53 in signaling checkpoint arrest or apoptosis. Curr. Opin. Genet. Dev. 6: 12-19.

Bellacosa, A., J.R. Testa, S.P. Staal, and P.N. Tsichlis. 1991. A retroviral oncogene, akt, encoding a serine/threonine kinase containing an SH2-like region. Science 254: 274-277.

Bellacosa, A., D.D. Feo, A.K. Godwin, D.W. Bell, J.Q. Cheng, D.A. Altomare, M. Wan, L. Dubeau, G. Scambia, V. Masciullo, G. Ferrandina, P.B. Panici, S. Mancuso, G. Neri, and J.R. Testa. 1995. Molecular alterations of the AKT2 oncogene in ovarian and breast carcinomas. Int. J. Cancer 64: 280-285.

Beretta, L., A.C. Gingras, Y.V. Svitkin, M.N. Hall, and N. Sonenberg. 1996. Rapamycin blocks the phosphorylation of $4 \mathrm{E}-\mathrm{BP} 1$ and inhibits cap-dependent initiation of translation. EMBO T. 15: 658-664.

Bissonnette, R.P., F. Echeverri, A. Mahboubi, and D.R. Green. 1992. Apoptotic cell death induced by c-myc is inhibited by bcl-2. Nature 359: 552-554.

Boudreau, N., C.J. Sympson, Z. Werb, and M.J. Bissell. 1995. Suppression of ICE and apoptosis in mammary epithelial cells by extracellular matrix. Science 267: 891-893.

Briscoe, C. and R.A. Firtel. 1995. Intercellular signaling. A kinase for cell-fate determination? Curr. Biol. 5: 228-231.

Brown, E.J. and S.L. Schreiber. 1996. A signaling pathway to translational control. Cell 86: 517-520.

Burgering, B.M. and P.J. Coffer. 1995. Protein kinase B (c-Akt) in phosphatidylinositol-3-OH kinase signal transduction. $\mathrm{Na}$ - 
ture 376: 599-602.

Christofori, G., P. Nalik, and D. Hanahan. 1994. A second signal supplied by insulin-like growth factor II in oncogene-induced tumorigenesis. Nature 369: 414-418.

Cross, D.A., D.R. Aless, P. Cohen, M. Andjelkovich, and B.A. Hemmings. 1995. Inhibition of glycogen synthase kinase- 3 by insulin mediated by protein kinase B. Nature 378: 785-789.

Datta, K., T.F. Franke, T.O. Chan, A. Makris, S. Yang, D.R. Kaplan, D.K. Morrison, E.A. Golemis, and P.N. Tsichlis. 1995. AH/PH domain/mediated interaction between Akt molecules and its potential role in Akt regulation. Mol. Cell. Biol. 15: 2304-2310.

Datta, K., A. Bellacosa, T.D. Chan, and P.N. Tsichlis. 1996. Akt is a direct target of the PI 3-kinase: Activation by growth factors, v-src and v-Ha-ras in Sf9 and mammalian cells. $J$. Biol. Chem. 271: 30835-30839.

Diaz-Meco, M.T., M.M. Municio, S. Frutos, P. Snachez, J. Lozano, L. Sanz, and J. Moscat. 1996. The product of par-4, a gene induced during apoptosis, interacts selectively with the atypical isoforms of protein kinase C. Cell 86: 777-786.

Eilers, M., D. Picard, K.R. Yamamoto, and J.M. Bishop. 1989. Chimaeras of Myc oncoprotein and steroid receptors cause hormone-dependent transformation of cells. Nature 340: 6668.

Ellis, R.E., J.Y. Yuan, and H.R. Horvitz. 1991. Mechanisms and functions of cell death. Ann. Rev. Cell Biol. 7: 663-698.

Enari, M., R.V. Talanian, W.W. Wong, and S. Nagata. 1996. Sequential activation of ICE-like and CPP32-like proteases during Fas-mediated apoptosis. Nature 380: 723-726.

Evan, G.I., A.H. Wyllie, C.S. Gilbert, T.D. Littlewood, H. Land, M. Brooks, C.M. Waters, L.Z. Penn, and D.C. Hancock. 1992. Induction of apoptosis in fibroblasts by c-myc protein. Cell 69: 119-128.

Fairbairn, L.J., G.J. Cowling, B.M. Reipert, and T.M. Dexter. 1993. Suppression of apoptosis allows differentiation and development of a multipotent hemopoietic cell line in the absence of added growth factors. Cell 74: 823-832.

Fanidi, A., E.A. Harrington, and G.I. Evan. 1992. Cooperative interaction between $\mathrm{c}-\mathrm{myc}$ and $\mathrm{bcl}-2$ proto-oncogenes. $\mathrm{Na}$ ture 359: 554-556.

Favaron, M., H. Manev, H. Alho, M. Bertolino, B. Ferret, A. Guidotti, and E. Costa. 1988. Gangliosides prevent glutamate and kainate neurotoxicity in primary neuronal cultures of neonatal rat cerebellum and cortex. Proc. Natl. Acad. Sci. 85: 7351-7355.

Franke, T.F., S. Yang, T.O. Chan, K. Datta, A. Kazlauskas, D.K. Morrison, D.R. Kaplan, and P.N. Tsichlis. 1995. The protein kinase encoded by the Akt proto-oncogene is a target of the PDGF-activated phosphatidylinositol 3-kinase. Cell 81: $727-736$.

Harrington, E.A., M.R. Bennett, A. Fanidi, and G.I. Evan. 1994. c-Myc-induced apoptosis in fibroblasts is inhibited by specific cytokines. EMBO I. 13: 3286-3295.

Hunter, T. 1995. When is a lipid kinase not a lipid kinase? When it is a protein kinase. Cell 83: 1-4.

Kapeller, R. and L.C. Cantley. 1994. Phoshatidylinositol 3-kinase. BioEssays 16: 565-576.

Kharbanda, S., A. Saleem, T. Shafman, Y. Emoto, N. Taneja, E. Rubin, R. Weichselbaum, J. Woodgett, J. Avruch, J. Kyriakis, and D. Kufe. 1995. Ionizing radiation stimulates a Grb2mediated association of the stress-activated protein kinase with phosphatidylinositol 3-kinase. I. Biol. Chem. 270: 18871-18874.

Kohn, A.D., K.S. Kovacina, and R.A. Roth. 1995. Insulin stimulates the kinase activity of Rac-PK, a pleckstrin homology domain containing ser/thr kinase. EMBO /. 14: 4288-4295.
Korsmeyer, S.J. 1995. Regulators of cell death. Trends Genet. 11: 101-105.

Koskinen, P.J., D.E. Ayer, and R.N. Eisenman. 1995. Repression of Myc-Ras cotransformation by Mad is mediated by multiple protein-protein interactions. Cell Growth Differ. 6: 623-629.

Koury, M.J. and M.C. Bondrant. 1990. Erythropoietin retards DNA break down and prevents programmed death in erythroid progenitor cells. Science 248: 378-381.

Kunz, J. and M.N. Hall. 1993. Cyclosporin A, FK506 and rapamycin, more than just immunosuppression. Trends Biochem. Sci. 18: 334-338.

Liu, Z.-g., H. Hsu, D.V. Goeddel, and M. Karin. 1996. Dissection of TNF receptor 1 effector functions: JNK activation is not linked to apoptosis while NF-kB activation prevents cell death. Cell 87: 565-567.

Matsumine, A., A. Ogai, T. Senda, N. Okumura, K. Satoh, G.H. Baeg, T. Kawahara, S. Kobayashi, M. Okada, K. Toyoshima, and T. Akiyama. 1996. Binding of APC to the human homo$\log$ of the Drosophila discs large tumor suppressor protein. Science 272: 1020-1023.

Miura, M., E. Surmacz, J.L. Burgaud, and R. Baserga. 1995. Different effects on mitogenesis and transformation of a mutation at tyrosine 1251 of the insulin-like growth factor I receptor. I. Biol. Chem. 270: 22639-22644.

Miyazaki, T., L. Zhao-Jun, A. Kawahara, Y. Minami, K. Yamada, Y. Tsujimoto, E.L. Barsoumian, R.M. Perlmutter, and T. Taniguchi. 1995. Three distinct IL-2 signaling pathways mediated by bcl-2, c-myc, and lck cooperate in hematopoietic cell proliferation. Cell 81: 223-231.

Morin, P.J., B. Vogelstein, and K.W. Kinzler. 1996. Apoptosis and APC in colorectal tumorigenesis. Proc. Natl. Acad. Sci. 93: 7950-7954.

Morris, J.Z., H.A. Tissenbaum, and G. Ruvkun. 1996. A phosphatidylinositol-3-OH kinase family member regulating longevity and diapause in Caenorhabditis elegans. Nature 382: 536-539.

Peifer, M. 1996. Regulating cell proliferation: As easy as APC. Science 272: 974-975.

Pleiman, C.M., W.M. Hertz, and J.C. Cambier. 1994. Activation of phosphatidylinositol-3' kinase by Src-family kinase SH3 binding to the p85 subunit. Science 263: 1609-1612.

Raff, M.C., B.A. Barres, J.F. Burne, H.S. Coles, Y. Ishizaki, and M.D. Jacobson. 1993. Programmed cell death and the control of cell survival: Lessons from the nervous system. Science 262: 695-700.

Resnicoff, M., D. Abraham, W. Yutanawiboonchai, H.L. Rotman, J. Kajstura, R. Rubin, P. Zoltick, and R. Baserga. 1995a. The insulin-like growth factor I receptor protects tumor cells from apoptosis in vivo. Cancer Res. 55: 2463-2469.

Resnicoff, M., J.L. Burgaud, H.L. Rotman, D. Abraham, and R. Baserga. 1995b. Correlation between apoptosis, tumorigenesis, and levels of insulin-like growth factor I receptors. Cancer Res. 55: 3739-3741.

Rodriguez-Viciana, P., P.H. Warne, R. Dhand, B. Vanhaesebroeck, I. Gout, M.J. Fry, M.D. Waterfield, and J. Downward. 1994. Phosphatidylinositol-3-OH kinase as a direct target of Ras. Nature 370: 527-532.

Rubinfeld, B., I. Albert, E. Porfiri, C. Fiol, S. Munemitsu, and P. Polakis. 1996. Binding of GSK3 $\beta$ to the APC- $\beta$-catenin complex and regulation of complex assembly. Science 272: 1023-1026.

Samuels, M.L., M.J. Weber, J.M. Bishop, and M. McMahon. 1993. Conditional transformation of cells and rapid activation of the mitogen-activated protein kinase cascade by an estradiol-dependent human Raf-1 protein kinase. Mol. Cell. Biol. 13: 6241-6252. 
Shi, Y., A. Frankel, L.G. Radvanyi, L.Z. Penn, R.G. Miller, and G.B. Mills. 1995. Rapamycin enhances apoptosis and increases sensitivity to cisplatin in vitro. Cancer Res. 55: 1982-1988.

Staal, S.P. 1987. Molecular cloning of the akt oncogene and its human homologues AKT1 and AKT2: Amplification of $A K T 1$ in a primary human gastric adenocarcinoma. Proc. Natl. Acad Sci. 84: 5034-5037.

Steller, H. 1995. Mechanisms and genes of cellular suicide. Science 267: 1445-1449.

Takahashi, A. and W.C. Earnshaw. 1996. ICE-related proteases in apoptosis. Curr. Opin. Genet. Dev. 6: 50-55.

Tewari, M., L.T. Quan, K. O'Rourke, S. Desnoyers, Z. Zeng, D.R. Beidler, G.G. Poirier, G.S. Salvesen, and V.M. Dixit. 1995. Yama/CPP32 $\beta$, a mammalian homolog of CED-3, is a CrmA-inhibitable protease that cleaves the death substrate poly/ADP-ribose) polymerase. Cell 81: 801-809.

Thompson, C.B. 1995. Apoptosis in the pathogenesis and treatment of disease. Science 267: 1456-1462.

Ueda, K. and D. Ganem. 1996. Apoptosis is induced by N-myc expression in hepatocytes, a frequent event in hepadnavirus oncogenesis, and is blocked by insulin-like growth factor II. J. Virol. 70: 1375-1383.

Uhlman, E.J., C. D'Sa-Eipper, T. Subramanian, A.J. Wagner, N. Hay, and G. Chinnadurai. 1996. Deletion of a nonconserved region of Bcl-2 confers a novel gain of function: Suppression of apoptosis with concomitant cell proliferation. Cancer Res. 56: 2506-2509.

Ui, M., T. Okada, K. Hazeki, and O. Hazeki. 1995. Wortmannin as a unique probe for an intracellular signaling protein, phosphoinisitide 3-kinase. Trends Biochem. Sci. 5: 303-306.

Verheij, M., R. Bose, X.H. Lin, B. Yao, W.D. Jarvis, S. Grant, M.J. Birrer, E. Szabo, L. Zon, J.M. Kyriakis, A. Halmovitz-Friedman, Z. Fuks, and R.N. Kolesnick. 1996. Requirement for ceramide-initiated SAPK/JNK signaling in stress-induced apoptosis. Nature 380: 75-79.

Wagner, A.J., M.B. Small, and N. Hay. 1993. Myc-mediated apoptosis is blocked by ectopic expression of Bcl-2. Mol. Cell. Biol. 13: 2432-2440.

Wagner, A.J., J.M. Kokontis, and N. Hay. 1994. Myc-mediated apoptosis requires wild-type $\mathrm{p} 53$ in a manner independent of cell cycle arrest and the ability of p53 to induce p $21^{\text {waf1/cip? }}$ Genes \& Dev. 8: 2817-2830.

Waterston, R., C. Martin, M. Craxton, C. Huynh, A. Coulson, L. Hillier, R. Durbin, P. Green, R. Shownkeen, N. Halloran, et al. 1992. A survey of expressed genes in Caenorhabditis elegans. Nature Genet. 1: 114-123.

Welsh, G.I., E.J. Foulstone, S.W. Young, J.M. Tavare, and C.G. Proud. 1994. Wortmannin inhibits the effects of insulin and serum on the activities of glycogen synthase kinase- 3 and mitogen-activated protein kinase. Biochem. J. 303: 15-20.

Wymann, M.P., G. Bulgarelli-Leva, M.J. Zvelebil, L. Pirola, B. Vanhaesebroeck, M.D. Waterfield, and G. Panayotou. 1996. Wortmannin inactivates phosphoinositide 3-kinase by covalent modification of Lys-802, a residue involved in the phosphate transfer reaction. Mol. Cell. Biol. 16: 1722-1733.

Xue, D., S. Shaham, and H.R. Horvitz. 1996. The Caenorhabditis elegans cell-death protein CED-3 is a cysteine protease with substrate specificites similar to those of the human CPP32 protease. Genes \& Dev. 10: $1073-1083$.

Yao, R. and G.M. Cooper. 1995. Requirement for phosphatidylinositol-3 kinase in the prevention of apoptosis by the nerve growth factor. Science 267: 2003-2005.

Yonish-Rouach, E., D. Resnitzky, J. Lotem, L. Sachs, A. Kimchi, and $M$. Oren. 1991. Wild-type p53 induces apoptosis of myeloid leukemic cells that is inhibited by interleukin-6. $\mathrm{Na}$ ture 353: 345-347. 


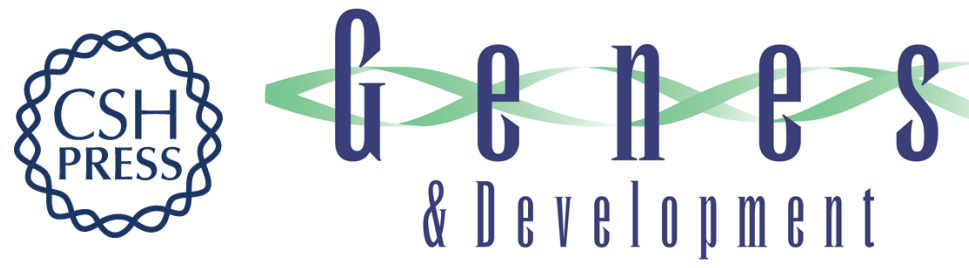

\section{The PI 3-kinase/Akt signaling pathway delivers an anti-apoptotic signal.}

S G Kennedy, A J Wagner, S D Conzen, et al.

Genes Dev. 1997, 11:

Access the most recent version at doi:10.1101/gad.11.6.701

References This article cites 63 articles, 31 of which can be accessed free at: http://genesdev.cshlp.org/content/11/6/701.full.html\#ref-list-1

License

Email Alerting

Service

Receive free email alerts when new articles cite this article - sign up in the box at the top right corner of the article or click here.

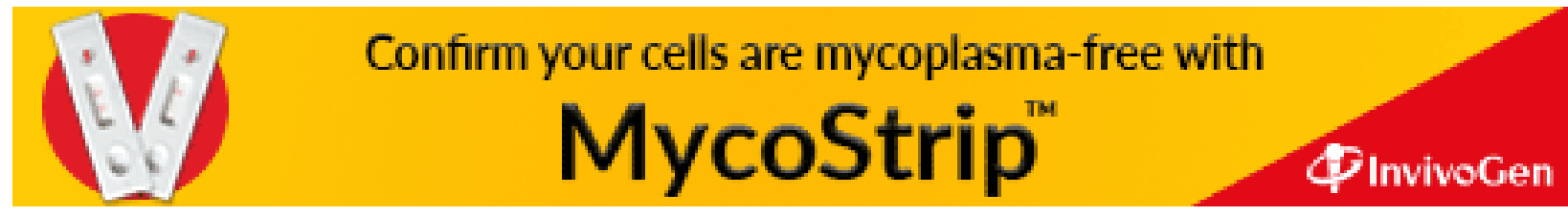

